\title{
SYNTHESIS, CHARACTERISATION AND ANTIMICROBIAL STUDIES OF MIXED LIGANDS METAL (II) COMPLEXES OF SULFAMETHOXAZOLE AND N,N- DONORS HETEROCYCLES
}

\author{
${ }^{* 1}$ Eugene-Osoikhia, T.T., ${ }^{1}$ Aleem, A. O and ${ }^{2}$ Ayeni, F \\ ${ }^{1}$ Department of Chemistry, University of Ibadan, Ibadan, Nigeria \\ ${ }^{2}$ Department of Pharmaceutical Microbiology, University of Ibadan, Ibadan, Nigeria \\ *Corresponding Author's email: kemitunmise@yahoo.co.uk Tel: +2348030487007
}

\begin{abstract}
Two mixed ligands of sulfamethoxazole (SMX) with N,N donor heterocycles: 1,10-phenanthroline (phen) and $2,2^{\prime}$-bipyridine (bipy) metal complexes having the composition $[\mathrm{M}(\mathrm{SMX})(\mathrm{phen}) \mathrm{X}] . \mathrm{nH}_{2} \mathrm{O}$ and $\left[\mathrm{M}(\mathrm{SMX})\left(\right.\right.$ bipy)X]. $\mathrm{nH}_{2} \mathrm{O}$ (where $\mathrm{M}=\mathrm{Zn}(\mathrm{II}), \mathrm{Co}(\mathrm{II}), \mathrm{Fe}(\mathrm{II}), \mathrm{Mn}$ (II), $\mathrm{Cu}(\mathrm{II}) ; \mathrm{X}=\mathrm{SO}_{4} / \mathrm{Cl}_{2}$ ) have been synthesised and characterised by physicochemical methods based on their solubility, metal analysis, infrared and UV-Visible techniques. Infrared spectra data showed SMX as a bidentate ligand coordinating to the metals through the $\mathrm{N}$ atom of the sulfonamide group $\left(\left(3195-3030 \mathrm{~cm}^{-1}\right)\right.$ and oxygen atom of the sulfonyl moiety (1158$1103 \mathrm{~cm}^{-1}$ ) while the heterocycles also bonded as bidentate ligands through their diimine nitrogen atoms (1606$1423 \mathrm{~cm}^{-1}$ ). The electronic spectra data indicated that all the metal (II) complexes were monomeric and octahedral. The in-vitro antimicrobial studies of these complexes and their ligands against environmental strains of microorganisms: Bacillus subtilis, Staphylococcus aureus, Pseudomonas aeruginosa, Escherichia coli, Aspergillus niger and Candida albicans showed that SMX-phen metal complexes $[\mathrm{M}(\mathrm{SMX})(\mathrm{phen}) \mathrm{X}] \cdot \mathrm{nH}_{2} \mathrm{O}$ are better heterocycle with zone of inhibition in the range $28-10 \mathrm{~mm}$ to combine with SMX for the enhancement of its antimicrobial spectrum this may be due to their more extensive aromatic ring system which gave better lipophilicity, hence aided cell membrane penetration and promoted hostile intracellular interactions leading to death of microoganisms.
\end{abstract}

Keywords: Sulfamethoxazole, 1,10-phenanthroline, mixed ligands, 2,2'-Bipyridine, antimicrobial, heterocycles

\section{INTRODUCTION}

Sulfamethoxazole (SMX) (Fig.1), a sulfonamide drug is a structural analoque of p-aminobenzoic acid that inhibits the synthesis of intermediary dihydrofolic acid from its precursors (Masters et al., 2003). It is a bacteriostatic antibiotic, used in synergistic combination therapy with Trimethoprim for the treatment of urinary tract infections, respiratory tract pathogens, skin pathogens, certain enteric pathogens (Silver, 2011); and as an substitute to amoxicillin-based antibiotics in treating sinusitis and prophylaxis of pneumonia in patients living with AIDS (Sayar et al., 2008). The clinical importance of sulfamethoxazole and trimethoprim-sulfamethoxazole combination has slowly declined in the most recent decades, largely as a result of the development and rapid spread of resistance to these agents among all major bacterial pathogens (Huovinen, 2001). Hence, the need to seek for an alternative combination for sulfamethoxazole which will also offer expanded spectrum of action against disease pathogens.

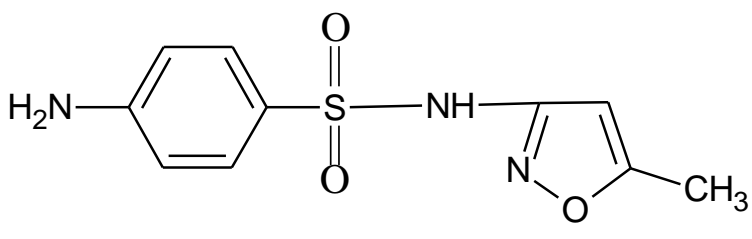

Figure 1: Structure of Sulfamethoxazole

Reported literatures have suggested that heterocycles and their derivatives have excellent broad spectrum of biological activities (Helio et al., 2006; Taghreed et al., 2015), so a search for a new drug from heterocycles is believed to support the chance of success (Tirkeso et al., 2019). Among the heterocycles, 1,10-Phenanthroline (phen) and 2,2' bipyridine (bipy) have extended planar $\pi$ systems and can be used in model compounds to copy the non covalent interactions in biological processes (Armani et al., 2007). Since its discovery at the end of nineteenth century (Shubert and Eschbaumer, 2002), the 2,2'bipyridine (bipy) (Fig. 2) ligand has been used extensively as a metal chelating ligand due to its robust redox stability and ease of functionalization (Kaes et al., 2000) . 1,10-Phenanthrolines (phen) (Fig.2) is a classic nitrogen heterocycle present in sterols, sex hormones, cardiac glycosides, bile acids and morphine 
alkaloids (Liscombe et al., 2005). It is chelating bidentate ligand for metal ions, which have played a vital role in the progress of coordination chemistry (Kitagawa et al., 2004; Kitagawa et al.,2006; Bencini and Lippolis, 2010), and still it continues to be of considerable interest as versatile starting material for organic, inorganic and supramolecular chemistry. 1,10Phenanthrolines is a rigid planar, hydrophobic, electron-poor heteroaromatic system whose nitrogen atoms are beautifully placed to act cooperatively in cation binding. These structural features determine its coordination ability towards metal ions (Selvaganapathy and Raman, 2016). Due to its excellent ability to coordinate with many metal ions, 1,10-phenanthrolines and its derivatives are often used in many processes involving metal complexes, for example, as ligands for catalysis (Schoffers, 2003), stabilizing agents for nanoparticle synthesis(Toshima et al., 2001), electroluminescent materials (Yang et al., 2012; Starosta et al., 2012; Yan and Gu, 2013), organic light-emitting devices (OLED) (Zhang et al.,2011),organic semiconductors (Zhao et al., 2011), antimicrobial agents (McCann et al., 2012; Santos et al., 2012; Raman et al., 2014) or as chemical nucleases and therapeutic agents, owing to their ability to bind or interact with the DNA biomacromolecule (Villar-Garcia et al., 2012; Li et al., 2012; Kellett et al., 2012).

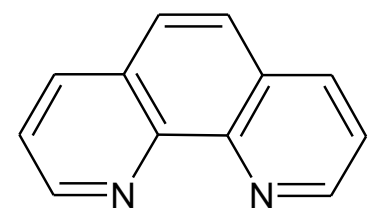

(a) 1,10-phenanthroline

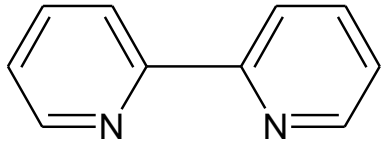

(b) 2,2'-bipyridine

Figure 2: Structures of the N,N-donors heterocycles used

In this report we present two different mixed ligands of sulfamethoxazole of 1,10-phenanthroline and 2,2'-bipyridine , their metal (II) complexes and their antimicrobial studies with the aim of comparing the extent to which each of these heterocycles can influence the antibacterial spectrum of sulfamethoxazole free drug.

\section{EXPERIMENTAL}

Materials and Reagents. All reagents and solvents were of analytical grade and used without further purification. Sulfamethoxazole was a gift from Unique pharmaceutical, Ogun State and Bond Pharmaceutical Company Plc, Awe, Oyo State, Nigeria. Cobalt (II) sulphate heptahydrate, Manganese (II) sulphate tetrahydrate, Zinc (II) sulphate heptahydrate, Iron (II) sulphate heptahydrate, Copper (II) chloride dihydrate, 1,10phenanthroline and 2,2'-bipyridine were obtained from Aldrich chemicals and used as supplied.

\section{Physical measurements}

The electronic spectra of the complexes in ethanol were recorded on a Perkin-Elmer Lambda 25 Spectrophotometer and infrared spectra were recorded using $\mathrm{KBr}$ discs on Perkin-Elmer BX II FT-IR spectrometer. Melting points were determined with Stuart SMP10 melting point apparatus and percentage metal was obtained by complexometric titration using EDTA.

Synthesis of Metal Complexes of [M(SMX)(phen)X].nH2O, where $\mathrm{M}=\mathrm{Cu}(\mathrm{II}), \mathrm{Co}(\mathrm{II}), \mathrm{Mn}(\mathrm{II}), \mathrm{Fe}(\mathrm{II})$ and $\mathrm{Zn}(\mathrm{II}) ; \mathrm{X}=\mathrm{SO}_{4}$ or $\mathrm{Cl}_{2}$

The complexes of mixed sulfamethoxazole and 1,10 phenanthroline ligands were synthesised using previously reported procedures (Alias and AbdulHassan, 2015). 0.2533g (1mmole) of sulfamethoxazole (SMX) in $5 \mathrm{ml}$ ethanol was added slowly to warm ethanolic solution of equimolar amount (1mmole) of the respective metal (II) salt. To the resulting mixture was added $0.1802 \mathrm{~g}$ ( $1 \mathrm{mmole}$ ) of 1,10 -phenanthroline (phen) in $5 \mathrm{ml}$ ethanol. The resulting homogeneous solution was refluxed for 3 hours with stirring and then cooled. Precipitates obtained were filtered, washed with ethanol and dried over silica gel.

Synthesis of Metal Complexes of $[\mathrm{M}(\mathrm{SMX})(\mathrm{bipy}) \mathrm{X}] . \mathrm{nH} 2 \mathrm{O}$,
where $\mathrm{M}=\mathrm{Cu}(\mathrm{II}), \mathrm{Co}(\mathrm{II}), \mathrm{Mn}(\mathrm{II}), \mathrm{Fe}(\mathrm{II})$ and $\mathrm{Zn}(\mathrm{II}) ; \mathrm{X}=\mathrm{SO}_{4}$
or $\mathrm{Cl}$

The complexes of mixed sulfamethoxazole and 2,2'-bipyridine ligands were synthesised using previously reported procedures (Alias and AbdulHassan, 2015). 0.2533g (1mmole) of sulfamethoxazole (SMX) in $5 \mathrm{ml}$ ethanol was added slowly to warm ethanolic solution of equimolar amount ( $1 \mathrm{mmole}$ ) of the respective metal (II) salt. To the resulting mixture was added $0.1562 \mathrm{~g}$ ( $1 \mathrm{mmole}$ ) of $2,2^{\prime}$-bipyridine (bipy) in $5 \mathrm{ml}$ ethanol. This was followed by the similar work up as indicated above.

\section{Antimicrobial studies}

Antibacterial screening of the free ligands and the synthesized complexes were tested in vitro using Agar diffusion method (Chaudhary et al., 2003; Shahzadi et al., 2006). Prepared culture plates were inoculated with different environmental strains of gram positive, gram negative bacteria and fungi: Bacillus subtilis, Staphylococcus aureus, Pseudomonas aeruginosa, Escherichia coli, Aspergillus niger and Candida albicans.

The bacteria were cultured using the pour-plate method. From the diluted organisms $\left(10^{-2}\right) 0-2 \mathrm{ml}$ was injected into the prepared sterile nutrient agar which was at $45^{\circ} \mathrm{C}$, then aseptically poured into sterile petri dishes, which were allowed to solidify for about 45-60minutes. Wells were made on the agar surface (Nutrient agar) with $6 \mathrm{~mm}$ sterile cork borer. The prepared different graded $(50 \mu \mathrm{g} / \mathrm{ml}$ and $10 \mu \mathrm{g} / \mathrm{ml})$ concentrations of the complexes and ligands were poured into the well using sterile syringes. The plates were incubated at 37 ${ }^{\circ} \mathrm{C} \pm 2{ }^{\circ} \mathrm{C}$ for 24 hours. The plates were observed for the zone clearance around the wells. The zone of inhibition was calculated by measuring the diameter of the inhibition zone 
around the well (in $\mathrm{mm}$ ) including the well diameter. The experiments were conducted in triplicates with Gentamycin used as positive control.

Sterile Sabourad Dextrose Agar was prepared for fungus culture. The prepared agar was poured into sterile plates in triplicates allowed to set properly. The organisms $(0.2 \mathrm{ml})$ (Aspergillus niger and Candida albicans) were spread to cover the surface of the agar. Wells were also made using sterile cork borer of $6 \mathrm{~mm}$ in diameter this was followed by the introduction of the prepared concentrations of the ligands and their complexes. The plates were left on the bench for 2 hours to allow pre diffusion and then incubated at $25 \pm 2{ }^{\circ} \mathrm{C}$ for 48 hours. Ketoconazole was used as the reference drug.

\section{RESULTS AND DISCUSSION}

The mixed ligands of sulfamethoxazole with $\mathrm{N}$, N-donor heterocycles; 1,10 phenanthroline and 2,2'-bipyridine with metal(II) salts of $\mathrm{Mn}, \mathrm{Co}, \mathrm{Zn}, \mathrm{Fe}$ and $\mathrm{Cu}$ gave varying shades of coloured complexes in low to moderate yields (17-60\%) as given in the Table 1 below. The ligands, sulfamethoxazole, 1,10 phenanthroline and $2,2^{\prime}$-bipyridine melted at $168-172^{\circ} \mathrm{C}, 117$ $118^{\circ} \mathrm{C}$ and $70-73^{\circ} \mathrm{C}$ respectively, whereas their metal complexes all decomposed on melting at temperature above $300^{\circ} \mathrm{C}$. They were insoluble in most solvents but were soluble in water, ethanol and DMSO. The analytical data are summarized in Table1 below

Table 1: Analytical data for sulfamethoxazole, 1,10-pheanthroline, 2,2-bipyridine and their complexes

\begin{tabular}{|c|c|c|c|c|c|}
\hline Compound & $\begin{array}{l}\text { Mol.Wt } \\
\text { (g/mol) }\end{array}$ & Colour & $\begin{array}{l}\% \\
\text { Yield }\end{array}$ & M.Pt $\left({ }^{0} \mathrm{C}\right)$ & $\begin{array}{l}\text { \%Metal } \\
\text { Exp (Calc) }\end{array}$ \\
\hline Sulfamethoxazole (SMX) & 253.28 & White & - & $168-172$ & - \\
\hline 1,10-phenanthroline (phen) & 180.21 & White & - & $117-118$ & - \\
\hline 2,2'-bipyridine (bipy) & 156.18 & White & - & $70-73$ & - \\
\hline$\left[\mathrm{Zn}(\mathrm{SMX})(\right.$ bipy$\left.) \mathrm{SO}_{4}\right] .3 \mathrm{H}_{2} \mathrm{O}$ & 626.87 & White & 28 & $300 *$ & $10.30(10.43)$ \\
\hline$\left[\mathrm{Co}(\mathrm{SMX})(\right.$ bipy $\left.) \mathrm{SO}_{4}\right] . \mathrm{H}_{2} \mathrm{O}$ & 584.39 & Pale pink & 18 & $300 *$ & $10.01(10.08)$ \\
\hline$\left[\mathrm{Fe}(\mathrm{SMX})(\right.$ bipy $\left.) \mathrm{SO}_{4}\right] .2 \mathrm{H}_{2} \mathrm{O}$ & 599.31 & Deep red & 42 & $300 *$ & $9.26(9.31)$ \\
\hline$\left[\mathrm{Mn}(\mathrm{SMX})(\right.$ bipy$\left.) \mathrm{SO}_{4}\right] \cdot 2 \mathrm{H}_{2} \mathrm{O}$ & 598.41 & Gold cream & 60 & $300 *$ & $9.24(9.18)$ \\
\hline$\left[\mathrm{Cu}(\mathrm{SMX})(\right.$ bipy $\left.) \mathrm{Cl}_{2}\right]$ & 543.91 & Light green & 17 & $300 *$ & $11.45(11.68)$ \\
\hline$\left[\mathrm{Zn}(\mathrm{SMX})(\mathrm{phen}) \mathrm{SO}_{4}\right] \cdot 2 \mathrm{H}_{2} \mathrm{O}$ & 632.90 & White & 35 & $300 *$ & $10.28(10.33)$ \\
\hline$\left[\mathrm{Co}(\mathrm{SMX})(\right.$ phen $\left.) \mathrm{SO}_{4}\right] \cdot 2 \mathrm{H}_{2} \mathrm{O}$ & 626.42 & Pale pink & 50 & $300 *$ & $9.22(9.41)$ \\
\hline$\left[\mathrm{Fe}(\mathrm{SMX})(\right.$ phen $\left.) \mathrm{SO}_{4}\right] \cdot 2 \mathrm{H}_{2} \mathrm{O}$ & 623.34 & Brick red & 38 & $300 *$ & $8.73(8.95)$ \\
\hline$\left[\mathrm{Mn}(\mathrm{SMX})(\right.$ phen $\left.) \mathrm{SO}_{4}\right] \cdot 2 \mathrm{H}_{2} \mathrm{O}$ & 604.42 & Gold cream & 42 & $300 *$ & $9.00(9.08)$ \\
\hline$\left[\mathrm{Cu}(\mathrm{SMX})(\right.$ phen $\left.) \mathrm{Cl}_{2}\right] \cdot 2 \mathrm{H}_{2} \mathrm{O}$ & 603.94 & Green & 52 & $300 *$ & $10.44(10.52)$ \\
\hline
\end{tabular}

\section{Infra red spectra studies of synthesized complexes}

The assignments of the peaks for the principal ligand sulfamethoxazole (SMX), co-ligands: 2,2'-bipyridine (bipy), 110-phenanthroline (phen) and their metal complexes are presented in Tables 2 and 3 respectively. The bonding of the ligands to metal ions was investigated by comparing the FTIR spectra of the complexes with those of the free ligands.

SMX is a positional ligand which may act as a bidentate or tridentate as illustrated by its structure, so its IR measurements are very signifying with respect to the complexation behaviour 
with various metal ions. Infrared spectrum of the free SMX ligand shows two strong bands at 3467 and $3377 \mathrm{~cm}^{-1}$ equivalent to the asymmetric and symmetric stretching vibrations of the aromatic amino group (Janiak, 2000). These aromatic amino $\left(\mathrm{v}\left(\mathrm{NH}_{2}\right)\right)$ band did not show any appreciable changes $\left( \pm 5 \mathrm{~cm}^{-1}\right)$ in all the complexes which demonstrated its non participation in the coordination with the metal centers (Rostamizadeh et al., 2019). The medium and strong signals of SMX at 3299 and $3240 \mathrm{~cm}^{-1}$ are due to the presence of asymmetric and symmetric frequency vibration of the sulfonamide -NH group. The multiband and shifting of sulfonamide $-\mathrm{NH}$ in the spectra of the prepared complexes, indicated the involvement of this group in chelation with central metal ion by nitrogen of this group (Mondelli et al., 2013). The SMX peak at $1621 \mathrm{~cm}^{-1}$ is connected to the methoxazole ring ( $v$ $(\mathrm{C}=\mathrm{N}))$ stretching vibration, which showed a very slight shift in the range of $\pm 4 \mathrm{~cm}^{-1}$ in the spectra of the metal complexes indicating the non- participation of this moiety in coordination with metal ions (Silverstein et al., 2005). 
Table 2: Relevant IR data of sulfamethoxazole, $2,2^{\prime}$-bipyridine and their complexes in $\mathrm{cm}^{-1}$

\begin{tabular}{|c|c|c|c|c|c|c|c|c|c|}
\hline Compounds & $\mathrm{V}(\mathrm{OH}) / \mathrm{H} 2 \mathrm{O}$ & $\begin{array}{l}v(\mathrm{NH} 2)(\mathrm{Ar} \\
\text { amino) }\end{array}$ & $\begin{array}{l}v(\mathrm{~N}-\mathrm{H}) \\
\text { (sulfonamide) }\end{array}$ & $\begin{array}{l}V(\mathrm{C}=\mathrm{N}) \\
\text { (methoxazole) }\end{array}$ & $\begin{array}{l}v(\mathrm{~S}=\mathbf{0}) \\
\text { (sulfonyl) }\end{array}$ & $\begin{array}{l}V(\mathrm{C}=\mathrm{C} / \mathrm{C}=\mathrm{N}) \\
(\text { diimine grp) }\end{array}$ & $V(M-N)$ & $v(M-O)$ & $\mathrm{V}(\mathrm{M}-\mathrm{Cl})$ \\
\hline Sulfamethoxazole (SMX) & - & $\begin{array}{l}\text { 3467(asy) } \\
\text { 3377(sym) }\end{array}$ & $\begin{array}{l}3299 \text { (asy) } \\
\text { 3240(sym) }\end{array}$ & 1621 & $\begin{array}{l}\text { 1307(asy) } \\
1188 \text { (sym) }\end{array}$ & - & - & - & - \\
\hline 2,2'-bipyridine (bipy) & - & - & - & - & - & $\begin{array}{l}1580,1557 \\
1453,1415\end{array}$ & - & - & - \\
\hline$\left[\mathrm{Zn}(\mathrm{SMX})(\right.$ bipy$\left.) \mathrm{SO}_{4}\right] \cdot 3 \mathrm{H}_{2} \mathrm{O}$ & $3490(b)$ & $\begin{array}{l}\text { 3465(asy) } \\
3373 \text { (sym) }\end{array}$ & $\begin{array}{l}\text { 3106(asy) } \\
3062 \text { (sym) }\end{array}$ & 1617 & $\begin{array}{l}\text { 1317(asy) } \\
1118 \text { (sym) }\end{array}$ & $\begin{array}{l}1599,1573 . \\
1492,1443\end{array}$ & 619 & 411 & - \\
\hline$\left[\mathrm{Co}(\mathrm{SMX})(\right.$ bipy $\left.) \mathrm{SO}_{4}\right] \cdot \mathrm{H}_{2} \mathrm{O}$ & $3356(b)$ & $\begin{array}{l}\text { 3469(asy) } \\
3377 \text { (sym) }\end{array}$ & $\begin{array}{l}\text { 3152(asy) } \\
\text { 3077(sym) }\end{array}$ & 1615 & $\begin{array}{l}\text { 1315(asy) } \\
1113 \text { (sym) }\end{array}$ & $\begin{array}{l}1599,1574 \\
1478,1447\end{array}$ & 570 & 415 & - \\
\hline$\left[\mathrm{Fe}(\mathrm{SMX})(\mathrm{bipy}) \mathrm{SO}_{4}\right] \cdot 2 \mathrm{H}_{2} \mathrm{O}$ & 3376 (b) & $\begin{array}{l}\text { 3466(asy) } \\
\text { 3381(sym) }\end{array}$ & $\begin{array}{l}3170 \text { (asy) } \\
3090 \text { (sym) }\end{array}$ & 1620 & $\begin{array}{l}\text { 1314(asy) } \\
1104 \text { (sym) }\end{array}$ & $\begin{array}{l}1597,1561 \\
1476,1445\end{array}$ & 612 & 484 & - \\
\hline$\left[\mathrm{Mn}(\mathrm{SMX})(\right.$ bipy $\left.) \mathrm{SO}_{4}\right] \cdot 2 \mathrm{H}_{2} \mathrm{O}$ & 3490 (b) & $\begin{array}{l}\text { 3467(asy) } \\
3380 \text { (sym) }\end{array}$ & $\begin{array}{l}\text { 3095(asy) } \\
3057 \text { (sym) }\end{array}$ & 1625 & $\begin{array}{l}\text { 1313(asy) } \\
1118 \text { (sym) }\end{array}$ & $\begin{array}{l}1592,1572 \\
1504,1435\end{array}$ & 546 & 413 & - \\
\hline$\left[\mathrm{Cu}(\mathrm{SMX})(\right.$ bipy $\left.) \mathrm{Cl}_{2}\right]$ & - & $\begin{array}{l}\text { 3470(asy) } \\
3383 \text { (sym) }\end{array}$ & $\begin{array}{l}\text { 3108(asy) } \\
3090 \text { (sym) }\end{array}$ & 1619 & $\begin{array}{l}\text { 1318(asy) } \\
1158 \text { (sym) }\end{array}$ & $\begin{array}{l}1596,1567 \\
1522,1444\end{array}$ & 546 & 418 & 392 \\
\hline
\end{tabular}

$\mathrm{b}=$ broad, asy $=$ asymmetric, sym $=$ symmetric, Ar. Amino = aromatic amino 
Table 3: Relevant IR data of sulfamethoxazole, 1,10-phenanthroline and their complexes in $\mathrm{cm}^{-1}$

\begin{tabular}{|c|c|c|c|c|c|c|c|c|c|}
\hline Compounds & $V(\mathrm{OH}) / \mathrm{H} 2 \mathrm{O}$ & $V_{(\mathrm{NH})(\operatorname{Ar} \text { amino })}$ & $\begin{array}{l}v(\mathrm{~N}-\mathrm{H}) \\
\text { (sulfonamide) }\end{array}$ & $\begin{array}{l}\nu(\mathrm{C}=\mathrm{N}) \\
\text { (methoxazole) }\end{array}$ & $\begin{array}{l}v(\mathrm{~S}=\mathbf{0}) \\
\text { (sulfonyl) }\end{array}$ & $\begin{array}{l}v(\mathrm{C}=\mathrm{C} / \mathrm{C}=\mathrm{N}) \\
\text { (diimine grp) }\end{array}$ & $V(\mathbf{M}-\mathbf{N})$ & $V(M-0)$ & $V(\mathrm{M}-\mathrm{Cl})$ \\
\hline Sulfamethoxazole (SMX) & - & $\begin{array}{l}3468(\text { asy })(\mathrm{s}) \\
3377(\mathrm{sym})(\mathrm{s})\end{array}$ & $\begin{array}{l}3299 \text { (asy) } \\
3240(\text { sym) }\end{array}$ & 1621 & $\begin{array}{l}1307 \text { (asy) } \\
1188 \text { (sym) }\end{array}$ & - & - & - & - \\
\hline 1,10-phenanthroline (phen) & - & - & - & - & - & $\begin{array}{l}1561,1503, \\
1492,1422\end{array}$ & - & - & - \\
\hline$\left[\mathrm{Zn}(\mathrm{SMX})(\mathrm{phen}) \mathrm{SO}_{4}\right] \cdot 2 \mathrm{H}_{2} \mathrm{O}$ & $3420(b)$ & $\begin{array}{l}\text { 3461(asy) } \\
\text { 3383(sym) }\end{array}$ & $\begin{array}{l}\text { 3081(asy) } \\
\text { 3049(sym) }\end{array}$ & 1621 & $\begin{array}{l}1308 \text { (asy) } \\
1103 \text { (sym) }\end{array}$ & $\begin{array}{l}1602,1521 \\
1462,1438\end{array}$ & 506 & 426 & - \\
\hline$\left[\mathrm{Co}(\mathrm{SMX})(\mathrm{phen}) \mathrm{SO}_{4}\right] .2 \mathrm{H}_{2} \mathrm{O}$ & 3500 (b) & $\begin{array}{l}\text { 3463(asy) } \\
3376 \text { (sym) }\end{array}$ & $\begin{array}{l}3195 \text { (asy) } \\
3060 \text { (sym) }\end{array}$ & 1621 & $\begin{array}{l}1306 \text { (asy) } \\
1146 \text { (sym }\end{array}$ & $\begin{array}{l}1581,1516 \\
1495,1425\end{array}$ & 504 & 411 & - \\
\hline$\left[\mathrm{Fe}(\mathrm{SMX})(\right.$ phen $\left.) \mathrm{SO}_{4}\right] .2 \mathrm{H}_{2} \mathrm{O}$ & 3352 (b) & $\begin{array}{l}\text { 3466(asy) } \\
3380 \text { (sym) }\end{array}$ & $\begin{array}{l}3100 \text { (asy) } \\
3070 \text { (sym) }\end{array}$ & 1624 & $\begin{array}{l}1305 \text { (asy) } \\
1111 \text { (sym }\end{array}$ & $\begin{array}{l}1576,1517 \\
1496,1428\end{array}$ & 603 & 424 & - \\
\hline$\left[\mathrm{Mn}(\mathrm{SMX})(\right.$ phen $\left.) \mathrm{SO}_{4}\right] \cdot 2 \mathrm{H}_{2} \mathrm{O}$ & 3465 (b) & $\begin{array}{l}\text { 3464(asy) } \\
\text { 3381(sym) }\end{array}$ & $\begin{array}{l}3110 \text { (asy) } \\
3030 \text { (sym) }\end{array}$ & 1623 & $\begin{array}{l}1306 \text { (asy) } \\
1147 \text { (sym) }\end{array}$ & $\begin{array}{l}1591,1577 \\
1517,1450\end{array}$ & 553 & 474 & - \\
\hline$\left[\mathrm{Cu}(\mathrm{SMX})(\right.$ phen $\left.) \mathrm{Cl}_{2}\right] \cdot 2 \mathrm{H}_{2} \mathrm{O}$ & 3490 (b) & $\begin{array}{l}\text { 3470(asy) } \\
3374 \text { (sym) }\end{array}$ & $\begin{array}{l}\text { 3080(asy) } \\
3044 \text { (sym) }\end{array}$ & 1625 & $\begin{array}{l}\text { 1309(asy) } \\
1146 \text { (sym) }\end{array}$ & $\begin{array}{l}1606,1514, \\
1495,1423\end{array}$ & 508 & 428 & 364 \\
\hline
\end{tabular}

$\mathrm{b}=$ broad, asy $=$ asymmetric, sym $=$ symmetric, Ar. Amino $=$ aromatic amino 
The asymmetric and symmetric stretching frequencies of the sulfonyl group $(\mathrm{O}=\mathrm{S}=\mathrm{O})$ in $\mathrm{SMX}$ were observed at 1307 and $1188 \mathrm{~cm}^{-1}$ respectively. The asymmetric sulfone band at $1307 \mathrm{~cm}^{-1}$ slightly shifted in the complexes which was indicative of non-coordination of one of the sulphone oxygen atoms, whereas the second sulphone band at $1188 \mathrm{~cm}^{-1}$ shifted to 1158 - $1104 \mathrm{~cm}^{-1}$ in $\left[\mathrm{M}(\mathrm{SMX})\right.$ (bipy)X]. $\mathrm{nH}_{2} \mathrm{O}$ and $1147-1103 \mathrm{~cm}^{-1}$ in [M(SMX)(bipy)X].nH2O metal complexes confirming coordination to the metal atom through the second sulfone oxygen atom

(Bamigboye et al., 2012). Based on these, the coordination mode of SMX with metal ions is predicted as a bidentate through the $\mathrm{N}$ atom of sulfonamide group and oxygen atom of the sulfonyl moiety for all the complexes.

The binding of the co-ligands phen and bipy was shown by the shift of the diimine $((\mathrm{C}=\mathrm{C}),(\mathrm{C}=\mathrm{N}))$ ring stretching vibration to higher frequencies in the spectra of all the complexes and confirming the coordination nature of co-ligands (Soliman and Mohamed, 2004; Anupama and Kumari, 2013; Abu-Hussen, 2006; Mukherjee, 2000). Also, new bands appeared in the range (484-411) $\mathrm{cm}^{-1}$ and (619-504) $\mathrm{cm}^{-1}$ due to the stretching frequencies of (M-O) and (M-N) bonds respectively. Another new bands at 364 and $392 \mathrm{~cm}^{-1}$ assigned to $\mathrm{M}-\mathrm{Cl}$ stretching vibrations appeared in the spectrum of $\left[\mathrm{Cu}(\mathrm{SMX})(\right.$ phen $\left.) \mathrm{Cl}_{2}\right] \cdot 2 \mathrm{H}_{2} \mathrm{O}$ and $\left[\mathrm{Cu}(\mathrm{SMX})(\right.$ bipy $\left.) \mathrm{Cl}_{2}\right]$ complexes respectively. In all the complexes except $\left[\mathrm{Cu}(\mathrm{SMX})(\right.$ bipy $\left.) \mathrm{Cl}_{2}\right]$ the presence of lattice/coordinated water molecules were indicated by the appearance of broad bands in the region 3352-3500 $\mathrm{cm}^{-1}$ (Rîmbu et al., 2014).

Electronic Spectra of the synthesised complexes

The electronic spectral absorptions of the ligands and complexes are presented in Table 4. The electronic spectrum of sulfamethoxazole (SMX) exhibited two absorption bands in the ultraviolet region, the band at $47169 \mathrm{~cm}^{-1}(212 \mathrm{~nm})$ assigned to the $\pi \rightarrow \pi^{*}$ transition for the intra ligand aromatic system $(\mathrm{C}=\mathrm{C})$ and the signal at $37037 \mathrm{~cm}^{-1}(270 \mathrm{~nm})$ to $\mathrm{n} \rightarrow \pi^{*}$ transition for oxygen atom of $\mathrm{S}=\mathrm{O}$ group or nitrogen atom of amine moiety and imine $-\mathrm{N}=\mathrm{C}-$ group, respectively (Zahid et al., 2009). In the electronic spectra of the heterocycles co-ligands: phen and bipy,the bands at $44247 \mathrm{~cm}^{-1}(226 \mathrm{~nm})$ and $43103 \mathrm{~cm}^{-1}(232 \mathrm{~nm})$ were assigned to $\pi \rightarrow \pi^{*}$ transition due to $\mathrm{C}=\mathrm{C}$ group while the signals at $37735 \mathrm{~cm}^{-1}(265 \mathrm{~nm}), \quad 35842 \mathrm{~cm}^{-1}(279 \mathrm{~nm})$ and $34482 \mathrm{~cm}^{-1}(290 \mathrm{~nm})$ were attributed to $\mathrm{n} \rightarrow \pi^{*}$ transition due to the nitrogen atom of the $-\mathrm{N}=\mathrm{C}-$ group (Wojciechowska et al., 2001; Scarborough and Wieghardt, 2011; Imam et al., 2011). In the metal complexes, these bands shifted to lower wave number due to coordination as presented in Table 4 .

The two zinc complexes $\mathrm{Zn}(\mathrm{SMX})\left(\right.$ bipy) $\left.\mathrm{SO}_{4}\right] \cdot 3 \mathrm{H}_{2} \mathrm{O}$ and $\left[\mathrm{Zn}(\mathrm{SMX})(\right.$ phen $\left.) \mathrm{SO}_{4}\right] .2 \mathrm{H}_{2} \mathrm{O}$ showed only the charge transfer transitions from metal to ligand, as no $\mathrm{d}$-d transition was expected due to their $\mathrm{d}^{10}$ configurations. These complexes assumed a 6-coordinate octahedral geometry (Raman et al., 2001; Onah et al., 2011). In the visible region, three bands were exhibited by $\left[\mathrm{Co}(\mathrm{SMX})\left(\right.\right.$ bipy)SO $\left.\mathrm{SO}_{4}\right] . \mathrm{H}_{2} \mathrm{O}$ at $16474 \mathrm{~cm}^{-1}(607 \mathrm{~nm})$, $19762 \mathrm{~cm}^{-1}(506)$ and $23752 \mathrm{~cm}^{-1}(421 \mathrm{~nm})$ and $\left[\mathrm{Co}(\mathrm{SMX})(\right.$ phen $\left.) \mathrm{SO}_{4}\right] .2 \mathrm{H}_{2} \mathrm{O}$ complex at $19762 \mathrm{~cm}^{-1}(506 \mathrm{~nm})$, $20920 \mathrm{~cm}^{-1}(478 \mathrm{~nm})$ and $23640 \mathrm{~cm}^{-1}(423 \mathrm{~nm})$, these signals were assigned to, ${ }^{4} \mathrm{~T}_{1 \mathrm{~g}(\mathrm{~F})} \rightarrow{ }^{4} \mathrm{~T}_{2 \mathrm{~g}(\mathrm{~F})},{ }^{4} \mathrm{~T}_{1 \mathrm{~g}(\mathrm{~F})} \rightarrow{ }^{4} \mathrm{~A}_{2 \mathrm{~g}(\mathrm{~F})}$ and ${ }^{4} \mathrm{~T}_{1 \mathrm{~g}(\mathrm{~F})} \rightarrow{ }^{4} \mathrm{~T}_{1 \mathrm{~g}(\mathrm{P})}$ transitions predicting octahedral geometry (Sarhan et al., 2011; Osowole et al., 2015).

A single absorption band at $16474 \mathrm{~cm}-1(607 \mathrm{~nm})$ and $15576 \mathrm{~cm}-$ $1(642 \mathrm{~nm})$ typical of 6-coordinate, high spin octahedral geometry and assigned to ${ }^{5} \mathrm{~T}_{2 \mathrm{~g}} \rightarrow{ }^{5} \mathrm{E}_{\mathrm{g}}$ were exhibited by $\left[\mathrm{Fe}(\mathrm{SMX})\left(\right.\right.$ bipy) $\left.\mathrm{SO}_{4}\right] \cdot 2 \mathrm{H}_{2} \mathrm{O}$ and $\left[\mathrm{Fe}(\mathrm{SMX})(\right.$ phen $\left.) \mathrm{SO}_{4}\right] \cdot 2 \mathrm{H}_{2} \mathrm{O}$ complexes respectively (Osowole et al., 2015). The electronic spectral of $\left[\mathrm{Cu}(\mathrm{SMZ})(\right.$ bipy) $\left.] \mathrm{Cl}_{2}\right]$ and $\left[\mathrm{Cu}(\mathrm{SMZ})(\right.$ phen $\left.) \mathrm{Cl}_{2}\right]$. $2 \mathrm{H}_{2} \mathrm{O}$ showed single broad band at $14771 \mathrm{~cm}^{-1}(677 \mathrm{~nm})$ and $14306 \mathrm{~cm}^{-1}(699 \mathrm{~nm})$ respectively assigned to ${ }^{2} \mathrm{Eg} \rightarrow{ }^{2} \mathrm{~T}_{2 \mathrm{~g}}$ transition was an indication of octahedral geometry as reported in literature (Sudhamani et al., 2009; Agwara et al., 2010; Scotti et al., 2015). The electronic absorption spectra of manganesecomplex $\left[\mathrm{Mn}(\mathrm{SMX})\left(\right.\right.$ bipy) $\left.\mathrm{SO}_{4}\right] \cdot 2 \mathrm{H}_{2} \mathrm{O}$ presents three major absorptions maxima at 24330, 15384, $13175 \mathrm{~cm}^{-1}$ and $\left[\mathrm{Mn}(\mathrm{SMX})(\right.$ phen $\left.) \mathrm{SO}_{4}\right] .2 \mathrm{H}_{2} \mathrm{O}$ at $23419,20703,15313 \mathrm{~cm}^{-1}$ which were assigned to ${ }^{6} \mathrm{~A}_{1 \mathrm{~g}} \rightarrow{ }^{4} \mathrm{~A}_{1 \mathrm{~g}},{ }^{6} \mathrm{~A}_{1 \mathrm{~g}} \rightarrow{ }^{4} \mathrm{~T}_{2 \mathrm{~g}}$ and ${ }^{6} \mathrm{~A}_{1 \mathrm{~g}} \rightarrow{ }^{4} \mathrm{~T}_{1 \mathrm{~g}}$ transitions typical of octahedral geometry(Singh and Chaudhary 2004; Sreekanth, et al., 2006),

FUDMA Journal of Sciences (FJS) Vol. 4 No. 2, June, 2020, pp 217 - 232 
Table 4: Electronic spectra data of sulfamethoxazole, 1,10-phenanthroline, 2,2' -bipyridine and their metal complexes

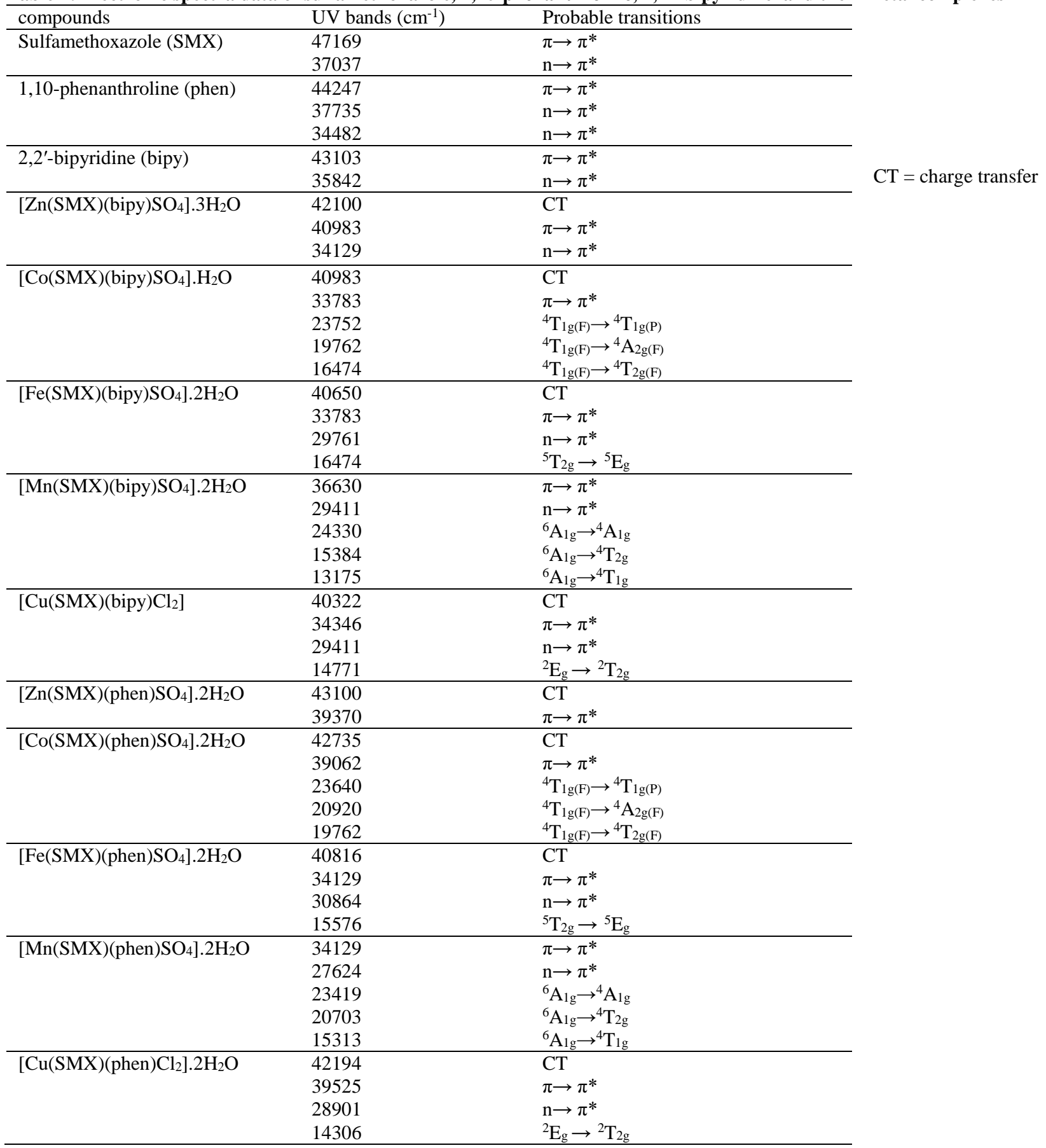




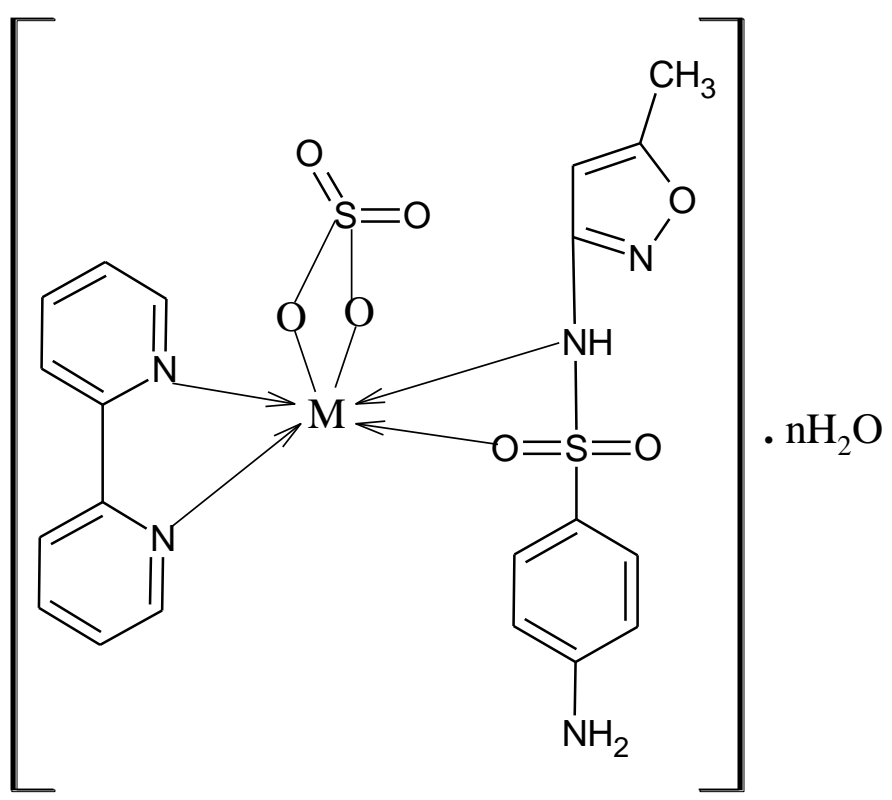

where $\mathrm{M}=\mathrm{Zn}, \mathrm{Co}, \mathrm{Fe}, \mathrm{Mn}$ and $\mathrm{n}=1,23$

Figure 3: Proposed structure of [M(SMX)(bipy)SO $\left.\mathrm{SO}_{4}\right] . \mathrm{nH} 2 \mathrm{O}$

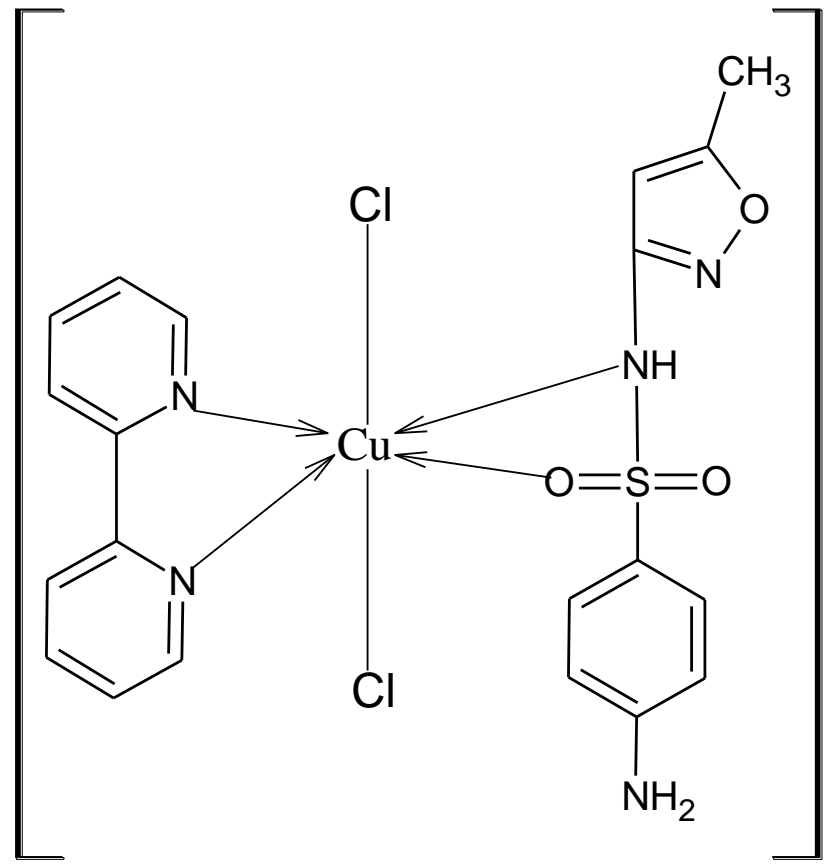

Figure 4: Proposed structure of $\left[\mathrm{Cu}(\mathrm{SMX})(\right.$ bipy $\left.) \mathrm{Cl}_{2}\right]$ 


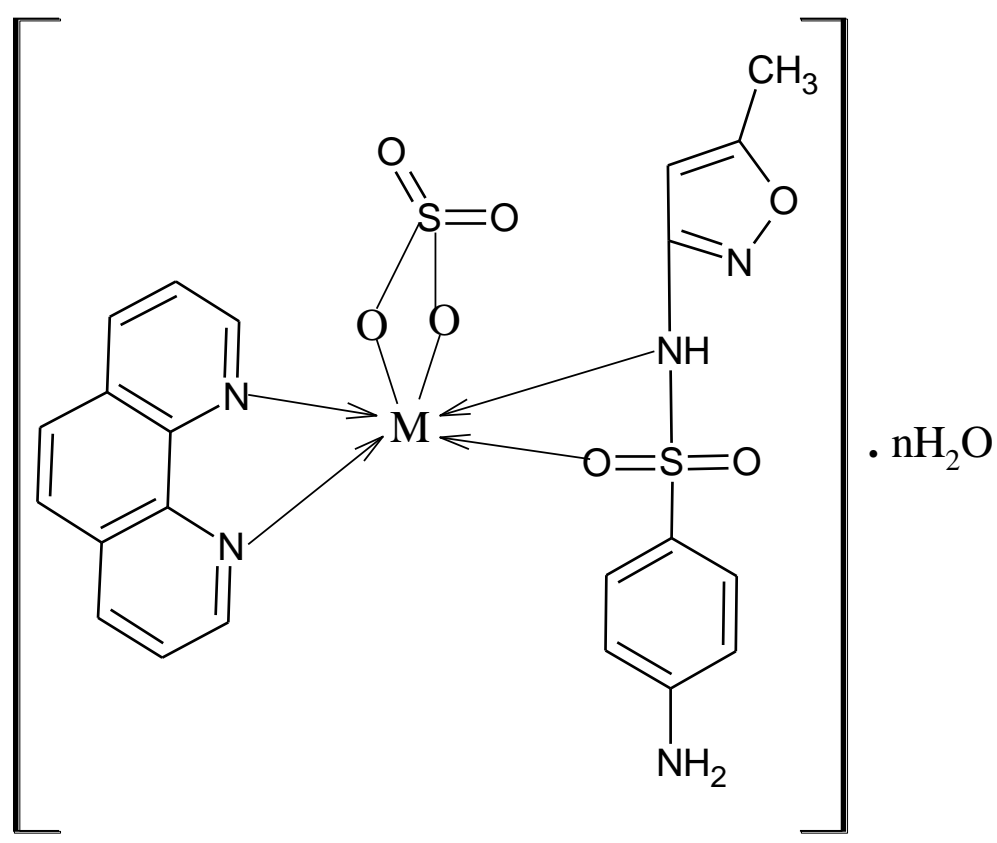

where $\mathrm{M}=\mathrm{Zn}, \mathrm{Co}, \mathrm{Fe}, \mathrm{Mn}$ and $\mathrm{n}=2$

Figure 5: Proposed structure of [M(SMX)(phen) $\left.\mathrm{SO}_{4}\right] . \mathrm{nH} 2 \mathrm{O}$

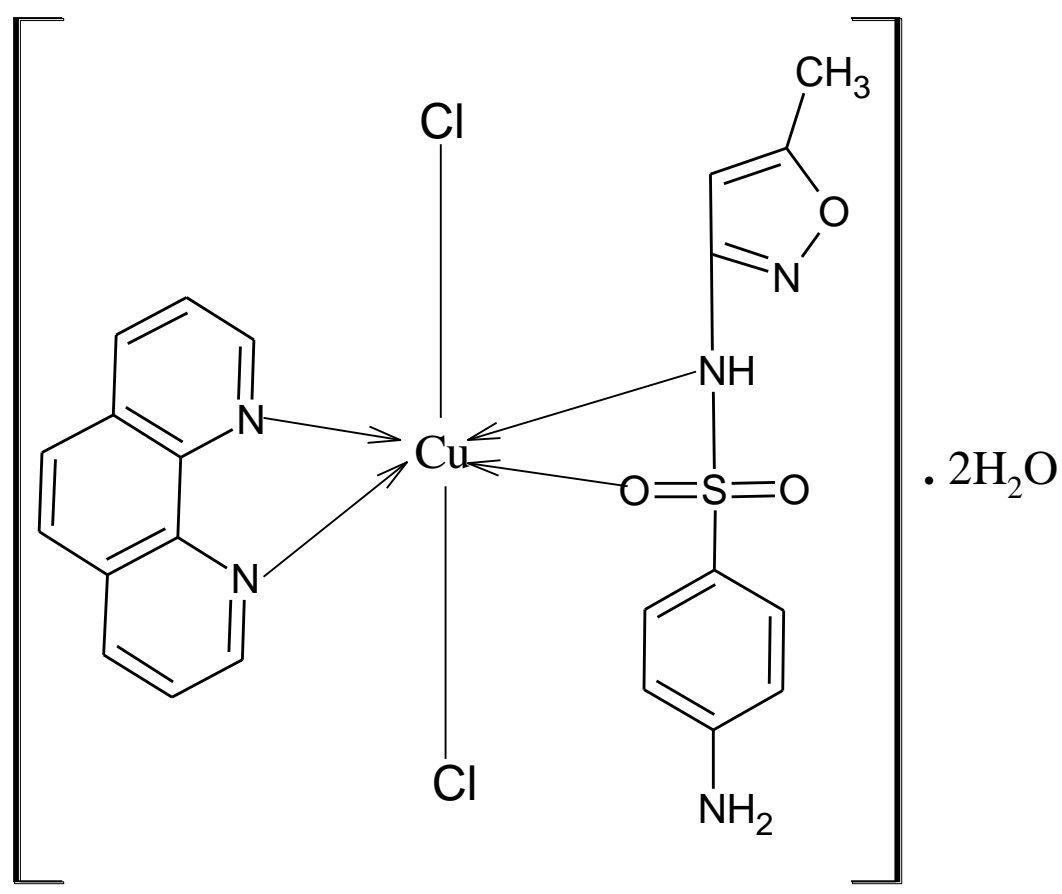

Figure 6: Proposed structure of $\left[\mathrm{Cu}(\mathrm{SMX})(\right.$ phen $\left.) \mathrm{Cl}_{2}\right] . \mathrm{nH} 2 \mathrm{O}$

\section{Antimicrobial studies}

The antimicrobial activities of the ligands Sulfamethoxazole (SMX), 1,10-phenanthroline (phen), 2,2'-bipyridine (bipy) and their metal complexes are presented in Table 5. The ligand phen exhibited the highest antimicrobial activities with zones of inhibition ranging from $24 \mathrm{~mm}$ to $30 \mathrm{~mm}$ at $50 \mu \mathrm{g} / \mathrm{ml}$ and 12 $18 \mathrm{~mm}$ at $10 \mu \mathrm{g} / \mathrm{ml}$. This was followed by SMX and lastly by bipy which exhibited selective antimicrobial activities against Staphylococcus aureus, Pseudomonas aeruginosa, Escherichia coli and Aspergillus niger at $50 \mu \mathrm{g} / \mathrm{ml}$ with zones of inhibition 
between $12-18 \mathrm{~mm}$, however, it showed no activity against all the tested microorganisms at $10 \mu \mathrm{g} / \mathrm{ml}$. The better antimicrobial activities exhibited by phen compare to bipy in this work might be attributed to the more extensive aromatic ring system of the phen molecule, which might confer on it greater lipophilicity and facilitate it to penetrate the cell membrane and promote adverse intracellular interactions (McCann et al., 2012) as well as the ability of phen to sequester essential trace metals (transition metals) from biological environments which has also been demonstrated to seriously impede the survival of microbial pathogens (Sevlever et al., 2001).

Generally, all the mixed ligand metal complexes were active against all tested microorganisms at $10 \mu \mathrm{g} / \mathrm{ml}$ except $\left[\mathrm{Fe}(\mathrm{SMX})(\right.$ bipy $\left.)\left(\mathrm{SO}_{4}\right)\right] \cdot 2 \mathrm{H}_{2} \mathrm{O}$ $\left[\mathrm{Mn}(\mathrm{SMX})\left(\right.\right.$ bipy) $\left.\left(\mathrm{SO}_{4}\right)\right] \cdot 2 \mathrm{H}_{2} \mathrm{O}$ exhibiting inactivities against Staphylococcus aureus, Pseudomonas aeruginosa, Escherichia coli and Aspergillus nigerat that concentrations. It was observed that the SMX-bipy metal complexes showed better activities than free bipy ligands but lower than the free SMX ligand. The observed trend for the SMX-bipy metal complexes was $\mathrm{Cu}>\mathrm{Zn}>\mathrm{Co}>\mathrm{Fe}>\mathrm{Mn}$ making $\left[\mathrm{Cu}(\mathrm{SMX})(\right.$ bipy $\left.) \mathrm{Cl}_{2}\right]$ the most biologically active among them.

On the other hand, SMX-phen metal complexes show greater antimicrobial activities at both $50 \mu \mathrm{g} / \mathrm{ml}$ and $10 \mu \mathrm{g} / \mathrm{ml}$ than their
SMX-bipy metal complexes counterparts. This observation was attributed to the more extensive aromatic ring system of the phen molecule included in their composition as earlier stated which gave the complexes better lipophilicity and aid their cell membrane penetration and promote adverse intracellular interactions (McCann et al., 2012). Among the SMX-phen metal complexes, $\left[\mathrm{Mn}(\mathrm{SMX})(\right.$ phen $\left.)\left(\mathrm{SO}_{4}\right)\right] \cdot 2 \mathrm{H}_{2} \mathrm{O}$ demonstrated the highest activity overall. Thus it can be inferred that phen $\mathrm{N}$, $\mathrm{N}$ donor heterocycle was better combination for SMX for enhancement of its antimicrobial spectrum.

Generally, the better activities demonstrated by all the mixed ligand complexes can be explained

on the basis of the Overtone's concept (Joseyphus and Nair, 2008) and Tweedy's chelation theory (Raman, et al., 2009). Chelation reduces the polarity of the metal ion considerably because of the partial sharing of its positive charge with the donor groups and also due to p-electron delocalization on the whole chelating ring increased lipophilicity enhances the penetration of the complexes into lipid membrane and blocking of all of the metal binding sites in the enzymes of microorganisms. These complexes also disturb the respiration process and thus block the synthesis of the proteins which restricts further growth of the organisms.

Table 5: Antimicrobial activities of Sulfamethoxazole, 1,10-phenanthroline, 2,2'-bipyridine ligands and their metal (II) complexes in mm

\begin{tabular}{|c|c|c|c|c|c|c|}
\hline Compound/Conc & B.S & S.A & P.A & E.C & A.N & C.A \\
\hline \multicolumn{7}{|l|}{ SMX } \\
\hline $50 \mu \mathrm{g} / \mathrm{ml}$ & $20 \pm 0.11$ & $17 \pm 0.32$ & $20 \pm 0.22$ & $27 \pm 0.00$ & $22 \pm 0.00$ & $23 \pm 0.88$ \\
\hline $10 \mu \mathrm{g} / \mathrm{ml}$ & $15 \pm 0.67$ & $12 \pm 0.21$ & $15 \pm 0.21$ & $17 \pm 0.33$ & $11 \pm 0.33$ & $10 \pm 0.00$ \\
\hline$+\mathrm{C}$ & $28 \pm 0.00$ & $28 \pm 0.00$ & $18 \pm 0.00$ & $20 \pm 0.00$ & $26 \pm 0.00$ & $26 \pm 0.00$ \\
\hline$-\mathrm{C}$ & - & - & - & - & - & - \\
\hline \multicolumn{7}{|l|}{ Phen } \\
\hline $50 \mu \mathrm{g} / \mathrm{ml}$ & $30 \pm 0.27$ & $28 \pm 0.14$ & $29 \pm 0.11$ & $26 \pm 0.14$ & $24 \pm 0.10$ & $25 \pm 0.04$ \\
\hline $10 \mu \mathrm{g} / \mathrm{ml}$ & $18 \pm 0.42$ & $17 \pm 0.32$ & $14 \pm 0.33$ & $16 \pm 0.23$ & $12 \pm 1.54$ & $13 \pm 0.88$ \\
\hline$+\mathrm{C}$ & $28 \pm 0.00$ & $28 \pm 0.00$ & $18 \pm 0.00$ & $20 \pm 0.00$ & $26 \pm 0.00$ & $26 \pm 0.00$ \\
\hline$-\mathrm{C}$ & - & - & - & - & - & - \\
\hline \multicolumn{7}{|l|}{ Bipy } \\
\hline $50 \mu \mathrm{g} / \mathrm{ml}$ & - & $11 \pm 1.13$ & $10 \pm 0.33$ & $15 \pm 1.15$ & $10 \pm 1.23$ & - \\
\hline $10 \mu \mathrm{g} / \mathrm{ml}$ & - & - & - & - & - & - \\
\hline$+\mathrm{C}$ & $28 \pm 0.00$ & $28 \pm 0.00$ & $18 \pm 0.00$ & $20 \pm 0.00$ & $26 \pm 0.00$ & $26 \pm 0.00$ \\
\hline$-\mathrm{C}$ & - & - & - & - & - & - \\
\hline \multicolumn{7}{|c|}{$\left[\mathrm{Zn}(\mathrm{SMX})(\right.$ bipy$\left.) \mathrm{SO}_{4}\right] \cdot 3 \mathrm{H}_{2} \mathrm{O}$} \\
\hline $10 \mu \mathrm{g} / \mathrm{ml}$ & $10 \pm 0.24$ & $6 \pm 1.13$ & - & - & $12 \pm 1.23$ & - \\
\hline$+\mathrm{C}$ & $28 \pm 0.00$ & $28 \pm 0.00$ & $18 \pm 0.00$ & $20 \pm 0.00$ & $26 \pm 0.00$ & $26 \pm 0.00$ \\
\hline$-\mathrm{C}$ & - & - & - & - & - & - \\
\hline
\end{tabular}

FUDMA Journal of Sciences (FJS) Vol. 4 No. 2, June, 2020, pp 217 - 232 


\begin{tabular}{|c|c|c|c|c|c|c|}
\hline $\begin{array}{l}{\left[\mathrm{Co}(\mathrm{SMX})(\mathrm{bipy})\left(\mathrm{SO}_{4}\right)\right] \cdot \mathrm{H}_{2} \mathrm{O}} \\
50 \mu \mathrm{g} / \mathrm{ml}\end{array}$ & $18 \pm 1.18$ & $15 \pm 1.19$ & $15 \pm 1.54$ & $20 \pm 1.13$ & $22 \pm 0.67$ & $23 \pm 0.33$ \\
\hline $10 \mu \mathrm{g} / \mathrm{ml}$ & - & - & - & - & $11 \pm 0.37$ & - \\
\hline$+\mathrm{C}$ & $28 \pm 0.00$ & $28 \pm 0.00$ & $18 \pm 0.00$ & $20 \pm 0.00$ & $26 \pm 0.00$ & $26 \pm 0.00$ \\
\hline$-\mathrm{C}$ & - & - & - & - & - & - \\
\hline \multicolumn{7}{|l|}{$\left[\mathrm{Fe}(\mathrm{SMX})(\right.$ bipy $\left.)\left(\mathrm{SO}_{4}\right)\right] .2 \mathrm{H}_{2} \mathrm{O}$} \\
\hline $50 \mu \mathrm{g} / \mathrm{ml}$ & $18 \pm 0.57$ & $20 \pm 0.26$ & - & $20 \pm 0.27$ & $21 \pm 0.54$ & $20 \pm 0.20$ \\
\hline $10 \mu \mathrm{g} / \mathrm{ml}$ & - & - & - & - & - & - \\
\hline$+\mathrm{C}$ & $28 \pm 0.00$ & $28 \pm 0.00$ & $18 \pm 0.00$ & $20 \pm 0.00$ & $26 \pm 0.00$ & $26 \pm 0.00$ \\
\hline$-\mathrm{C}$ & - & - & - & - & - & - \\
\hline \multicolumn{7}{|l|}{$\left[\mathrm{Mn}(\mathrm{SMX})(\right.$ bipy $\left.)\left(\mathrm{SO}_{4}\right)\right] \cdot 2 \mathrm{H}_{2} \mathrm{O}$} \\
\hline $50 \mu \mathrm{g} / \mathrm{ml}$ & $16 \pm 0.54$ & - & - & $12 \pm 0.45$ & - & - \\
\hline $10 \mu \mathrm{g} / \mathrm{ml}$ & - & - & - & - & - & - \\
\hline$+\mathrm{C}$ & $28 \pm 0.00$ & $28 \pm 0.00$ & $18 \pm 0.00$ & $20 \pm 0.00$ & $26 \pm 0.00$ & $26 \pm 0.00$ \\
\hline$-\mathrm{C}$ & - & - & - & - & - & - \\
\hline \multicolumn{7}{|l|}{$\left[\mathrm{Cu}(\mathrm{SMX})(\right.$ bipy $\left.) \mathrm{Cl}_{2}\right]$} \\
\hline $50 \mu \mathrm{g} / \mathrm{ml}$ & $20 \pm 0.22$ & $16 \pm 0.13$ & $22 \pm 0.23$ & $19 \pm 0.17$ & $24 \pm 0.57$ & $22 \pm 0.37$ \\
\hline $10 \mu \mathrm{g} / \mathrm{ml}$ & $18 \pm 1.28$ & - & $16 \pm 1.44$ & $13 \pm 0.13$ & $10 \pm 0.26$ & $20 \pm 1.10$ \\
\hline$+\mathrm{C}$ & $28 \pm 0.00$ & $28 \pm 0.00$ & $18 \pm 0.00$ & $20 \pm 0.00$ & $26 \pm 0.00$ & $26 \pm 0.00$ \\
\hline$-\mathrm{C}$ & - & - & - & - & - & - \\
\hline \multicolumn{7}{|l|}{$\left[\mathrm{Zn}(\mathrm{SMX})(\right.$ phen $\left.) \mathrm{SO}_{4}\right] .2 \mathrm{H}_{2} \mathrm{O}$} \\
\hline $10 \mu \mathrm{g} / \mathrm{ml}$ & $16 \pm 0.54$ & $16 \pm 0.56$ & $18 \pm 1.11$ & $12 \pm 0.45$ & $10 \pm 0.21$ & $12 \pm 0.45$ \\
\hline$+\mathrm{C}$ & $28 \pm 0.00$ & $28 \pm 0.00$ & $18 \pm 0.00$ & $20 \pm 0.00$ & $26 \pm 0.00$ & $26 \pm 0.00$ \\
\hline$-\mathrm{C}$ & - & - & - & - & - & - \\
\hline \multicolumn{7}{|l|}{$\left[\mathrm{Co}(\mathrm{SMX})(\right.$ phen $\left.)\left(\mathrm{SO}_{4}\right)\right] .2 \mathrm{H}_{2} \mathrm{O}$} \\
\hline $10 \mu \mathrm{g} / \mathrm{ml}$ & $14 \pm 0.32$ & $14 \pm 0.03$ & $12 \pm 0.13$ & $16 \pm 0.51$ & - & - \\
\hline$+\mathrm{C}$ & $28 \pm 0.00$ & $28 \pm 0.00$ & $18 \pm 0.00$ & $20 \pm 0.00$ & $26 \pm 0.00$ & $26 \pm 0.00$ \\
\hline$-\mathrm{C}$ & - & - & - & - & - & - \\
\hline \multicolumn{7}{|l|}{$\left[\mathrm{Fe}(\mathrm{SMX})(\right.$ phen $\left.)\left(\mathrm{SO}_{4}\right)\right] \cdot 2 \mathrm{H}_{2} \mathrm{O}$} \\
\hline $50 \mu \mathrm{g} / \mathrm{ml}$ & $23 \pm 0.33$ & $21 \pm 0.55$ & $24 \pm 0.27$ & $25 \pm 0.77$ & $26 \pm 0.27$ & $22 \pm 0.27$ \\
\hline $10 \mu \mathrm{g} / \mathrm{ml}$ & $16 \pm 0.45$ & $110 \pm 0.25$ & - & $12 \pm 0.65$ & $10 \pm 0.34$ & - \\
\hline$+\mathrm{C}$ & $28 \pm 0.00$ & $28 \pm 0.00$ & $18 \pm 0.00$ & $20 \pm 0.00$ & $26 \pm 0.00$ & $26 \pm 0.00$ \\
\hline$-\mathrm{C}$ & - & - & - & - & - & - \\
\hline \multicolumn{7}{|l|}{$\left[\mathrm{Mn}(\mathrm{SMX})(\right.$ phen $\left.)\left(\mathrm{SO}_{4}\right)\right] \cdot 2 \mathrm{H}_{2} \mathrm{O}$} \\
\hline $50 \mu \mathrm{g} / \mathrm{ml}$ & $28 \pm 0.37$ & $28 \pm 2.07$ & $28 \pm 1.17$ & $26 \pm 0.29$ & $22 \pm 0.65$ & $21 \pm 0.27$ \\
\hline $10 \mu \mathrm{g} / \mathrm{ml}$ & $18 \pm 0.12$ & $13 \pm 0.16$ & $16 \pm 0.21$ & $14 \pm 0.22$ & $10 \pm 0.46$ & $10 \pm 0.20$ \\
\hline$+\mathrm{C}$ & $28 \pm 0.00$ & $28 \pm 0.00$ & $18 \pm 0.00$ & $20 \pm 0.00$ & $26 \pm 0.00$ & $26 \pm 0.00$ \\
\hline$-\mathrm{C}$ & - & - & - & - & - & - \\
\hline \multicolumn{7}{|l|}{$\left[\mathrm{Cu}(\mathrm{SMX})(\right.$ phen $\left.) \mathrm{Cl}_{2}\right] \cdot 2 \mathrm{H}_{2} \mathrm{O}$} \\
\hline $50 \mu \mathrm{g} / \mathrm{ml}$ & $23 \pm 0.30$ & $21 \pm 0.13$ & $22 \pm 0.23$ & $23 \pm 0.61$ & $26 \pm 0.27$ & $20 \pm 0.70$ \\
\hline
\end{tabular}

FUDMA Journal of Sciences (FJS) Vol. 4 No. 2, June, 2020, pp 217 - 232 


\begin{tabular}{lllcccc}
\hline $10 \mu \mathrm{g} / \mathrm{ml}$ & $10 \pm 0.18$ & $12 \pm 0.26$ & $11 \pm 0.75$ & $15 \pm 0.12$ & $14 \pm 0.20$ & $13 \pm 0.10$ \\
$+\mathrm{C}$ & $28 \pm 0.00$ & $28 \pm 0.00$ & $18 \pm 0.00$ & $20 \pm 0.00$ & $26 \pm 0.00$ & $26 \pm 0.00$ \\
$-\mathrm{C}$ & - & - & - & - & - & -
\end{tabular}

Data are mean of three replicates $(\mathrm{n}=3) \pm$ standard error; $-C=D M S O,+C($ for bacteria $)=$ Gentamycin,$+\mathrm{C}$ for fungi $=$ Ketoconazole, B.S = Bacillus subtilis, S.A = Staphylococcus aureus, $P . A=$ Pseudomonas aeruginosa E.C = Escherichia coli, A.N = Aspergillus niger, $C . A=$ Candida albicans

\section{CONCLUSION}

Mixed ligands of sulfamethoxazole (SMX) with N,N donor heterocycles: 1,10-phenanthroline (phen) and 2,2-bipyridine (bipy) metal complexes having the composition $[\mathrm{M}(\mathrm{SMX})($ phen $) \mathrm{X}] \cdot \mathrm{nH} 2 \mathrm{O}$ and $[\mathrm{M}(\mathrm{SMX})($ bipy $) \mathrm{X}] \cdot \mathrm{nH}_{2} \mathrm{O}$ (where $\mathrm{M}=\mathrm{Zn}$ (II) , Co(II) , Fe (II), Mn (II), Cu(II) ; X = $\mathrm{SO}_{4} / \mathrm{Cl}_{2}$ ) have been synthesised and characterised by physicochemical methods based on their solubility, metal analysis, infrared and UV-Visible techniques. From the infrared spectra data, SMX behaves as a bidentate ligand bonding to the metals via the $\mathrm{N}$ atom of the sulfonamide group and oxygen atom of the sulfonyl moiety while the heterocycles (phen and bipy) coordinated through their diimine nitrogen atoms. The electronic spectra data showed that all the metal(II) complexes were monomeric and octahedral. The antimicrobial studies showed

that $[\mathrm{M}(\mathrm{SMX})(\mathrm{phen}) \mathrm{X}] \cdot \mathrm{nH}_{2} \mathrm{O}$ exhibited greater antimicrobial activities at both $50 \mu \mathrm{g} / \mathrm{ml}$ and $10 \mu \mathrm{g} / \mathrm{ml}$ than their SMX-bipy metal complexes counterparts this might be due to the more extensive aromatic ring system of the phen molecule included in their composition which gave the complexes better lipophilicity and aided their cell membrane penetration and promoted adverse intracellular interactions.

\section{ACKNOWLEDGEMENT}

The authors thank Bond Chemical Plc Awe, Oyo State and Unique Pharmaceutical Lagos State for the gift of Sulfamethoxazole and Mr. Sunday of Pharmaceutical Microbiology Department, University of Ibadan, Oyo State, Nigeria is appreciated for his technical assistance.

\section{REFERENCES}

Abu-Hussen, A.A.A. (2006). Synthesis and spectroscopic studies on ternary bis-Schiff-base complexes having oxygen and/or nitrogen donors. Journal of Coordination Chemistry, 59(2): 157-176.

Agwara, M. O., Ndifon, P. I., Ndosiri, N. B., Paboudam, A. G., Yufanyi, D. M. and Mohamadou, A. (2010). Synthesis, characterization and antimicrobial activities of $\mathrm{Co}(\mathrm{II}), \mathrm{Cu}(\mathrm{II})$ and $\mathrm{Zn}$ (II) mixed - Ligand complexes containing 1,10-phenanthroline and 2, 2'- bipyridine. Bulletin of the Chemical Society of Ethiopia, 24(3):383-389.

Alias, M.F and AbdulHassan, M. M. (2015). Synthesis and Characterization of Some Metal Complexes with their Sulfamethoxazoleand 4,4'-dimethyl-2,2'-bipyridyl and study Cytotoxic Effect on Hep-2 Cell Line. Baghdad Science Journal, 12(4): 740-751.

Anupama, B. and Kumari, C.G. ( 2013). Cobalt (II) complexes of ONO donor Schiff bases and N, N donor ligands: synthesis, characterization, antimicrobial and DNA binding study.
International Journal of Research in Chemistry and Environment, 3(2): 172-180.

Armani, V., Safari, N and Khavasi, H.R. (2007). Synthesis, characterization and crystal structure determination of iron(III) hetero-ligand complexes containing 2,2'-bipyridine, 5,5'dimethyl-2,2'bipyridine and chloride, [Fe(bipy)Cl 4$][$ bipy $\cdot \mathrm{H}]$ and $\left[\mathrm{Fe}(\mathrm{dmbipy})_{2} \mathrm{Cl}_{2}\right]\left[\mathrm{FeCl}_{4}\right]$. Polyhedron, 26(15): 4257-426.

Bamigboye, M.O., Obaleye, J.A and Abdulmolib, S. (2012). Synthesis, characterization and antimicrobial activity of some mixed sulfamethoxazole-cloxacillin metal drug complexes. International Journal of Chemistry, 22(2): 105-108.

Bencini, A and Lippolis, V. (2010). 1,10-Phenanthroline: A versatile building block for the construction of ligands for various purposes. Coordination Chemistry Reviews, 254(1718): 2096-2180.

Chaudhary, A., Bansal, N., Gajraj, A and Singh, R.V. (2003). Antifertility, Antibacterial, Antifungal and Percent Disease Incidence Aspects of Macrocyclic Complexes of Manganese (II). Journal of Inorganic Biochemistry, 96: 393-400.

Helio, G. B., Rosalia, A., Clarissa, P. F., Nilo, Z and Marcos, A. P. M. (2006). Recent advances in the chemistry of 1,10 phenanthrolines and their metal complex derivatives: synthesis and

promising applications in medicine. Technology and Catalysis, 19:1-3.

Huovinen, P. (2001). Resistance to TrimethoprimSulfamethoxazole. Clinical Infectious Diseases, 32:1608-1614.

Imam H , Kumar B. and Shafayat M.D.(2011).Mixed Ligand Complexes of Transition Metal Chelates of 1- nitroso-2naphthol and 8-hydroxyquinoline with Picolinic Acid and Quinaldinic acid. Oriental Journal of Chemistry, 27 (1): 287291.

Janiak, C. (2000). A critical account on $\pi-\pi$ stacking in metal complexes with aromatic nitrogen-containing ligands. Journal of Chemical Society Dalton Transactions, 21: 3885-3896.

Joseyphus, R.S and Nair, M.S. (2008).Antibacterial and antifungal studies on some schiff base complexes of zinc (II). Mycobiology, 36(2):93-98.

Kaes, C., Katz, A and Hosseini, M.W. (2000). Bipyridine: The Most Widely Used Ligand. A Review of Molecules Comprising at Least Two 2, 2'-Bipyridine Units. Chemical Reviews, 100(10): 3553-3590

FUDMA Journal of Sciences (FJS) Vol. 4 No. 2, June, 2020, pp $217-232$ 
Kitagawa, S., Noro, S and Nakamura, T. (2006). Pore surface engineering of microporous coordination polymers. Chemical Communications, 7: 701-707.

Kitagawa, S., Kitaura, R and Noro, S. (2004). Functional porous coordination polymers. Angewandte Chemie International edition, 43(18): 2334-2375.

Kellett, A., Howeb, O., Connor, M., McCann, M., Creaven, B. S., McClean, S., Foltyn-ArfaKia, A.,Casey, A and Devereux, M. (2012). Radical-induced DNA damage by cytotoxic squareplanar copper (II) complexes incorporating o-phthalate and 1, 10-phenanthroline or 2, 2'-dipyridyl. Free Radical Biology and Medicine, 53:564-576.

Li, Q., Sun, D., Zhou, Y., Liu, D., Zhang, Q and Liu, J.(2012). Anticancer activity of novel ruthenium complex with 1, 10phenanthrolineselenazole as potent telomeric G-quadruplex inhibitor. Inorganic Chemical Communications, 20: 142-146.

Liscombe, D.K., MacLeod, B. P., Loukanina, N., Nandi, O. I and Facchini, P. J. (2005)

Evidence for the monophyletic evolution of benzylisoquinoline alkaloid biosynthesis in angiosperms. Phytochemistry, 66(20): $2500-2520$

Masters, P.A., O’Bryan, T.A., Zurlo, J., Miller, D. Q and Joshi, N. (2003). Trimethoprim-Sulfamethoxazole Revisited. Archives of Internal Medicine, 163: 403-410.

McCann, M., Kellett, A., Kavanagh, K., Devereux, M and $\underline{\text { Santos, }}$ A. L. S. (2012). Deciphering the antimicrobial activity of phenanthroline chelators. Current Medicinal Chemistry, 19(17): 2703-2714.

Mondelli, M., Pavan, F., de Souva, P.C., Leite,C.Q., Ellena, J., Nascimento, O.R., Facchin, G and Torre, M.H. (2013).Study of A Series of Cobalt(II) Sulfonamide Complexes: Synthesis, spectroscopic characterization, and microbiological evaluation against M. Tuberculosis. Crystal Structure of [Co (Sulfamethoxazole)2(H2O)2]·H2O. Journal of Molecular Structure, 1036: 180-187

Mukherjee, R. (2000). Coordination chemistry with pyrazolebased chelating ligands: molecular structural aspects. Coordination Chemistry Reviews, 203(1): 151-218.

Osowole, A. A.,Wakil, S.M and Alao, O.K. (2015). Synthesis, Characterization and Antimicrobial Activity of Some Mixed Scotti, N., Ravasio, N., Psaro, R., Evangelisti, C., Trimethoprim -Sulfamethoxazole Metal Drug Complexes. World Dworakowska, S., Bogdal, D and Zaccheria, F. (2015). Copper Applied Sciences Journal, 33(2): 336-342.
Raman, N., Sakthivel, A and Rajasekaran, K. J. (2009) . Transition metal complexes with Schiff-base ligands: 4aminoantipyrine based derivatives-a review. Journal of Coordination Chemistry, 62(5): 691-709.

Raman, N., Mahalakshmi, R and Mitu L.( 2014). Bio-sensitive activities of coordination compounds containing 1,10phenanthroline as co-ligand: synthesis, structural elucidation and DNA binding properties of metal(II) complexes. Spectrochimica Acta Part A: Molecular and Biomolecular Spectroscopy, 131: 355-364.

Rîmbu, C., Danac, R and Pui, A. (2014). Antibacterial Activity of Pd(II) Complexes With Salicylaldehyde-Amino Acids Schiff Bases Ligands. Chemical and Pharmaceutical Bulletin, 62(1): 12-15.

Rostamizadeh, S., Daneshfar, Z and Moghimi, H. (2019). Synthesis of sulfamethoxazole and sulfabenzamide metal complexes; evaluation of their antibacterial activity. European Journal of Medicinal Chemistry, 171: 364-371.

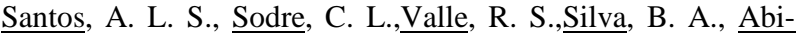
Chacra, E. A., Silva, L. V., Souza-Goncalves, A. L., Sangenito, L. S., Goncalves, D. S., Souza, L. O. P., Palmeira, V. F., d'AvilaLevy, C. M., Kneipp, L. F., Kellett, A., McCann, M and Branquinha, M. H. (2012). Antimicrobial action of chelating agents: repercussions on the microorganism development, virulence and pathogenesis. Current Medicinal Chemistry, 19(17): 2715-2737.

Sarhan, B.M., Waheed, E.J. and Naema, B.Z. (2011). Synthesis containing N-Acetyl Tryptophan and alpha-picoline with some metal salts. Ibn Al-Haitham Journal for Pure and Applied Science 24(1):1-12

Sayar, E., Şahin, S., Cevheroğlu, Ş and Hincal, A. A. (2008). Comparison of dissolution profiles of two commercially available Co-Trimoxazole tablets. FABAD Journal of Pharmaceutical Sciences, 33: 87-94.

Scarborough, C.C and Wieghardt, K. (2011). Electronic structure of 2, 2'-bipyridine organotransition-metal complexes. Establishing the ligand oxidation level by density functional theoretical calculations. Inorganic Chemistry, 50(20): 97739793.

Schoffers, E.(2003). Reinventing Phenanthroline Ligands Chiral Derivatives for Asymmetric Catalysis?. European Journal of Organic Chemistry, 2003 (7): 1145-1152. mediated epoxidation of high oleic natural oils with a cumene$\mathrm{O}_{2}$ system.

Catalysis Communication, 64: 80-85. and characterization of some mixed-ligand complexes

FUDMA Journal of Sciences (FJS) Vol. 4 No. 2, June, 2020, pp 217 - 232 
Selvaganapathy, M and Raman, N. (2016). Pharmacological Activity of a Few Transition Metal Complexes: A Short Review. Journal of Chemical Biology \& Therapeutics, 1(2): 1-17

Sevlever, D., Mann, K.J and Medof, M.E. (2001). Differential effect of 1, 10-phenanthroline on mammalian, yeast, and parasite glycosylphosphatidylinositol anchor synthesis. Biochemical and Biophysical Research Communications, 288(5): 1112-1118.

Shahzadi, S., Ali, S., Bhatti, M.H., Fettouhi, M and Athar, M. (2006). Chloro-diorganotin (IV) complexes of 4-methyl-1piperidine carbodithioic acid: Synthesis, X-ray crystal structures, spectral properties and antimicrobial studies. Journal of Organometallic Chemistry,691(8): 1797-1802.

Shubert, U.S and Eschbaumer, C. (2002). Macromolecules Containing Bipyridine and Terpyridine Metal Complexes: Towards Metallosupramolecular Polymers. Angewandte Chemie International edition, 41(16): 2892-2926

Silver, L. L. (2011). Challenges of Antibacterial Discovery. Clinical Microbiology Reviews, 24(1): 71-109

Silverstein, R. M., Webster, F. X. and Kiemle, D. J. (2005). Spectrometric identification of organic compound, 7th ed. Johnwiley. New York.

Singh, R.V and Chaudhary, A. (2004). Biologically relevant tetraazamacrocyclic complexes of manganese: synthetic, spectral, antimicrobial, antifertility and antiinflammatory approach. Journal of Inorganic Biochemistry, 98(11): 17121721.

Soliman, A.A. and Mohamed, G.G. (2004). Study of the ternary complexes of copper with salicylidene-2-aminothiophenol and some amino acids in the solid state. Thermochimica Acta, 421(1): 151-159.

Sreekanth, A., Joseph, M., Fun, H.K and Kurup, M.R.P. (2006). Formation of manganese (II) complexes of substituted thiosemicarbazones derived from 2-benzoylpyridine: Structural and spectroscopic studies. Polyhedron, 25(6): 1408-1414.

Starosta, R., Komarnicka, U. K., Sobczyk, M and Barys, M. (2012). Laser induced multi-component luminescence of [CuNCS (1,10-phen) P (CH2N (CH2CH2) 2O) 3] - the first example of CuNCS complexes with diimines and tris(aminomethyl)_phosphanes. Journal of Luminescence, 132(8): 1842-1847.

Sudhamani, C.N., Naik, H.S.B., Naik, T.R.R. and Prabhakara, M.C. (2009). Synthesis, DNA binding and cleavage studies of $\mathrm{Ni}$ (II) complexes with fused aromatic N-containing ligands. Spectrochimica Acta Part A: Molecular and Biomolecular Spectroscopy,72(3):643-647.
Taghreed, H. A., Israa, A.J. I. and Mohmmud, M. J.( 2015). Studies on the interaction and effect of $\mathrm{Mn}$ (II), Fe(II), Co(II), $\mathrm{Ni}(\mathrm{II}), \mathrm{Cu}(\mathrm{II}), \mathrm{Zn}(\mathrm{II})$ and $\mathrm{Cd}(\mathrm{II})$ mixed-ligand complexes of cephalexin mono hydrate and furan-2-carboxylic acid to different DNA sources. Journal of Chemical and Pharmaceutical Research, 7(4): 815-816.

Tirkeso, R. A., Tsega, T. W and Amdemichael, T. (2019). Synthesis, Characterization, and Antibacterial Activities of $1 \mathrm{H}-$ Imidazo [5, 6-f] [1,10] Phenanthroline-2(3H)-Thione and Its $\mathrm{Ni}(\mathrm{II})$ and $\mathrm{Cu}$ (II) Complexes. Journal of Chemistry, 2019 :1-10.

Toshima, N., Shiraishi, Y., Teranishi, T., Miyake, M.,Tominaga, T., Watanabe, H., Brijoux, W.,

Bonnemann, H and Schmid, G. (2001). Various ligandstabilized metal nanoclusters as homogeneous and heterogeneous catalysts in the liquid phase. Applied Organometallic Chemistry, 15(3): 178-196.

Villar-Garcia, I. J., Abebe, A and Chebude, Y. (2012). 1, 10Phenanthrolinium ionic liquids exhibiting excellent solubility for metal complexes: Potential solvents for biphasic and supported ionic liquid phase (SILP) Catalysis. Inorganic Chemistry Communications, 19: 1-3

Wojciechowska, A., Staszak, Z., Bronowska, W., Pietraszko, A and Cieslak-Golonka, A. (2001). Spectroscopic and structural studies of chromate ions in zinc complexes with 2, 2'-bipyridine. Analysis of the lowest triplet states in the CrO42- entity. Polyhedron, 20(15-16): 2063-2072.

Yan, B and Gu, Y. J. (2013). A novel white-luminescent ternary europium hybrids with phenanthroline functionalized periodic mesoporous organosilicas (PMOs) and 2-methyl-9hydroxyphenalenone. Inorganic Chemistry Communication, 34: 75-78.

Yan, B and Gu, Y. J. ( 2013). A novel white-luminescent ternary europium hybrids with phenanthroline functionalized periodic mesoporous organosilicas (PMOs) and 2-methyl-9hydroxyphenalenone. Inorganic Chemistry Communication, 34, 75-78.

FUDMA Journal of Sciences (FJS) Vol. 4 No. 2, June, 2020, pp $217-232$ 
Zhang, H. G., Tao, X. T., Chen, K. S., Yuan, C. X and Jiang, M.

Yang, C., Luo, J., Ma, J., Zhu, D., Miao, L., Zhang, Y., Liang, $\mathrm{L}$ and $\mathrm{Lu}, \mathrm{M}$. (2012). Luminescent properties and $\mathrm{CH} 3 \mathrm{COO}-$ recognition of europium complexes with different phenanthroline derivatives as second ligands. Synthetic Metals, 162(13-14): 1097-1106.

Zhao, J.F., Chen, L., Sun, P.J. Hou, X.Y., Zhao, X.H., Li, W.J., Xie, L.H.,Qian, Y., Shi, N.E., Lai, W.Y., Fan, Q.L and Huang, W. (2011). One-pot synthesis of 2-bromo-4, 5-diazafluoren-9one via a tandem oxidation-bromination-rearrangement of phenanthroline and its hammer-shaped donor-acceptor organic semiconductors. Tetrahedron, 67(10): 1977-1982.
H. (2011). Synthesis and photophysical properties of a new twophoton absorbing chromophor containing imidazo [4, 5-f][1, 10] phenanthroline. Synthetic Metals, 161(3-4): 354-359.

Zahid H. Chohan, Hazoor A. Shad and Nasim F. H. (2009).Synthesis, characterization and biological properties of sulfonamide derived compounds and their transition metal complexes. Applied Organometallic Chemistry, 23(8): 319-328.

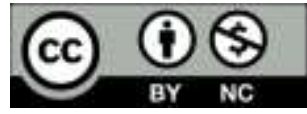

(C)2020 This is an Open Access article distributed under the terms of the Creative Commons Attribution 4.0 International license viewed via https://creativecommons.org/licenses/by/4.0/ which permits unrestricted use, distribution, and reproduction in any medium, provided the original work is cited appropriately.

FUDMA Journal of Sciences (FJS) Vol. 4 No. 2, June, 2020, pp $217-232$ 